\title{
Purification and partial characterization of an intracellular NADH:quinone oxidoreductase from Phanerochaete chrysosporium
}

\author{
Daniel Constam, $\dagger$ Andreas Muheim, Wolfgang Zimmermann* and Armin Fiechter \\ Department of Biotechnology, Swiss Federal Institute of Technology, ETH-Hoenggerberg, CH 8093 Zurich, Switzerland
}

(Received 22 October 1990; revised 15 February 1991; accepted 24 May 1991)

\begin{abstract}
Phanerochaete chrysosporium produced several intracellular NADH:quinone oxidoreductases under agitated, nitrogen-limited cultivation conditions. One of the quinone reductases was purified and shown to have a molecular mass of $69 \mathrm{kDa}$ by SDS-PAGE, while the molecular mass determined by gel filtration was $47 \mathrm{kDa}$. This reductase was separated by IEF into four protein bands, each with quinone reductase activity. The isoelectric points of the proteins were 5.7, 5.9, $6 \cdot 0$ and 6.3. The proteins reduced several quinones to the corresponding hydroquinones, but none of them was specific to any one of the quinones tested. Mycelial extracts of $\boldsymbol{P}$. chrysosporium contained several more quinone reductases, with isoelectric points of 4·4, 4·7, 5.0,5·3, 5.5 and 6.6. Quinone reductase activity could be induced by adding vanillic acid or 2-methoxy-1,4-benzoquinone to the growth medium in nitrogen-limited cultures and in carbon-limited cultures.
\end{abstract}

\section{Introduction}

The basidiomycete Phanerochaete chrysosporium produces several enzymes involved in the degradation of the plant cell wall biopolymer lignin (Tien \& Kirk, 1983; Gold et al., 1984). Among these enzymes, lignin peroxidases play a central role, but they are not the only factor necessary for the degradation of lignin to $\mathrm{CO}_{2}$. In vitro, they polymerize rather than depolymerize lignin (Hämmerli et al., 1986). Schoemaker et al. (1989) suggested that quinone metabolism might be one of these other factors, since various substituted quinones have been identified as key intermediates in the degradation of lignin model compounds (Ander et al., 1980; Buswell \& Eriksson, 1988; Higuchi, 1985; Schoemaker \& Leisola, 1987; Schoemaker et al., 1989). The rapid metabolism of quinones was proposed as a mechanism for shifting the equilibrium from enzymic polymerization to the depolymerization of lignin.

Several quinone reductases have been described which

$\dagger$ Present address: Section of Clinical Immunology and Department of Neurosurgery, University Hospital, Zurich, Switzerland.

Abbreviations: IEF, isoelectric focusing; MTT tetrazolium, 3-(4,5dimethyl thiazol-2-yl)-2,5-diphenyltetrazolium bromide; QI, quinone I (2-hydroxymethyl-5-methoxy-2,5-cyclohexadiene-1,4-dione); QII, quinone II (2-methoxy-2,5-cyclohexadiene-1,4-dione); QIII, quinone III (4,5-dimethoxy-3,5-cyclohexadiene-I,2-dione); QIV, quinone IV (2methoxy-5-(methoxymethyl)-2,5-cyclohexadiene). could be responsible for catalysing the first step in the degradation of quinones. One of these reductases is dependent on cellobiose as co-substrate and is produced extracellularly (Westermark \& Eriksson, 1974a,b). The hypothesis that this reductase is involved in the degradation of lignin was supported by two observations (Ander et al., 1990): firstly, the polymerization of kraft lignin by lignin peroxidase was decreased in the presence of this reductase; secondly, this reductase was shown to interact with laccase and different peroxidases, thereby increasing the decarboxylation of the lignin model compound vanillic acid. Another intracellular NAD(P)H:quinone oxidoreductase was described which reduces 2-methoxyquinone and several other synthetic quinones (Buswell et al., 1979; Buswell \& Eriksson, 1988). Later studies showed that $P$. chrysosporium produces at least two different intracellular quinone reductases. These may be part of a system which allows the fungus to take up small fragments of lignin and to degrade them intracellularly (Shoemaker et al., 1989). Each of these intracellular quinone reductases was suggested to reduce only one of the different quinones produced by the enzymic oxidation of the lignin model compound veratryl alcohol (Fig. 1).

We describe here the purification and characterization of an intracellular quinone reductase from $P$. chrysosporium that uses 2-hydroxymethyl-5-methoxy-1,4benzoquinone, 2-methoxy-1,4-benzoquinone and 2methoxy-5-(methoxymethyl)-1,4-benzoquinone as sub- 
<smiles>COC1=CC(=O)C(CO)=CC1=O</smiles>

Quinone I (QI)<smiles>COC1=CC(=O)C=CC1=O</smiles>

Quinone II (QII)<smiles>COC1=CC(=O)C(=O)C=C1OC</smiles>

Quinone III (QIII)<smiles>COCC1=CC(=O)C(OC)=CC1=O</smiles>

Quinone IV (QIV)

Fig. 1. Structural formulae of the quinones used in this study.

strates, all of which are products of the oxidative degradation of veratryl alcohol or its methyl ether by lignin peroxidase (Schmidt et al., 1989).

\section{Methods}

Chemicals. NADH and 2-methoxyhydroquinone were from Fluka. The quinones 2-hydroxymethyl-5-methoxy-2,5-cyclohexadiene-1,4dione (QI) and 2-methoxy-2,5-cyclohexadiene-1,4-dione (QII) as well as 4,5-dimethoxy-3,5-cyclohexadiene-1,2-dione (QIII) and 2-methoxy5-(methoxymethyl)-2,5-cyclohexadiene (QIV) were prepared according to Schmidt et al. (1989). The structures of QI-QIV are shown in Fig. 1.

The hydroquinones corresponding to QI and QIV were prepared according to Fieser \& Fieser (1967) by the reduction of the quinones with $\mathrm{Na}_{2} \mathrm{~S}_{2} \mathrm{O}_{4}$.

Culture conditions. The white-rot fungus Phanerochaete chrysosporium (ATCC 24725) was maintained on $2 \%(\mathrm{w} / \mathrm{v})$ malt agar slants at $4{ }^{\circ} \mathrm{C}$. Twelve one-litre Erlenmeyer flasks were inoculated with $10^{4}$ spores $\mathrm{ml}^{-1}$. Each flask contained $600 \mathrm{ml} \mathrm{N}$-or C-limited medium (Muheim et $a l ., 1990)$. The fungus was cultivated for $3.5 \mathrm{~d}$ on a rotary shaker $(150$ r.p.m.) at $37^{\circ} \mathrm{C}$.

Enzyme assay. Quinone reductase activity was measured in $25 \mathrm{mM}-$ Tris/ $/ \mathrm{HCl}$, pH 8.0, with $250 \mu \mathrm{M}-\mathrm{QI}$, II, III or IV and $200 \mu \mathrm{M}-\mathrm{NADH}$. The decrease in absorbance at $340 \mathrm{~nm}$ due to NADH oxidation was monitored spectrophotometrically at $23^{\circ} \mathrm{C}$. NADH is also oxidized non-enzymically by the quinones. The rate of this reaction was measured in a blank containing no enzyme, and its value was subtracted from that of the sample containing enzyme in a dual-path spectrophotometer (Perkin Elmer). The rate of non-enzymic quinone reduction by DTT was also subtracted, when this compound was tested as an inhibitor of the quinone reductases.

One unit of enzyme was defined as the amount oxidizing $1 \mu \mathrm{mol}$ NADH $\min ^{-1}$ at $23^{\circ} \mathrm{C}$ and $\mathrm{pH} \mathrm{8.0.} \mathrm{The} \mathrm{NADH} \mathrm{concentration} \mathrm{was}$ calculated using the equation $\Delta A=\left[\left(\varepsilon_{\mathrm{NADH}}+\Delta C_{\mathrm{NADH}}\right)+\left(\varepsilon_{\mathrm{Q}}+\Delta C_{\mathrm{Q}}\right)\right]$ $\times l$, where $C=$ concentration and $l=$ path length. Since $1 \mathrm{~mol}$ NADH reduces $1 \mathrm{~mol}$ quinone, $\Delta C_{\mathrm{NADH}}$ is equal to $\Delta C_{\mathrm{Q}}$. Therefore $\Delta A=$ $\left(\varepsilon_{\mathrm{NADH}}+\varepsilon_{\mathrm{Q}}\right) \times \Delta C \times l$. The absorption coefficients $\varepsilon=\varepsilon_{\mathrm{NADH}}+\varepsilon_{\mathrm{Q}}$ obtained for QI, QII and QIV were 7.796, 7.374 and 7.027 $\mathrm{mM}^{-1} \mathrm{~cm}^{-1}$, respectively.

The protein concentration was determined according to Bradford (1976)

Enzyme purification. The mycelial pellets were washed twice with distilled water and once with $50 \mathrm{~mm}$-Tris/HCl buffer, $\mathrm{pH} 7.5$, containing $1 \mathrm{~mm}$-EDTA. The pellets were suspended in $800 \mathrm{ml}$ of the same buffer, homogenized for $5 \mathrm{~min}$ with a Polytron mixer (Kinematica, Luzern, Switzerland) and centrifuged at $40000 \mathrm{~g}$ for $20 \mathrm{~min}$ at $4{ }^{\circ} \mathrm{C} . \mathrm{CaCl}_{2}(4 \mathrm{M})$ and $50 \%$ (w/v) PEG were added to the supernatant to give final concentrations of $16 \mathrm{~mm}$ and $10 \%$, respectively. The solution was stirred for $30 \mathrm{~min}$ and then centrifuged at $40000 \mathrm{~g}$ for $20 \mathrm{~min}$ at $4{ }^{\circ} \mathrm{C}$.

Swollen Blue Sepharose CL-6B gel (Pharmacia) $(80 \mathrm{ml})$ was equilibrated with $25 \mathrm{~mm}-\mathrm{Tris} / \mathrm{HCl}, \mathrm{pH} 7.5$, containing $2 \mathrm{mM}-\mathrm{CoCl}_{2}$. The gel was added to $720 \mathrm{ml}$ of the supernatant for the adsorption of quinone reductases and other nucleotide-dependent enzymes (Lowe \& Pearson, 1984). After stirring for $15 \mathrm{~min}$, the suspension was filtered through a sintered glass filter. The gel was packed on a column $(32 \mathrm{~mm}$ diameter), which was then equilibrated with the same buffer. At a flow rate of $100 \mathrm{ml} \mathrm{h}^{-1}$, quinone reductases were eluted with $25 \mathrm{mM}$ Tris/ $\mathrm{HCl}, \mathrm{pH} 8.0$, containing $0.5 \mathrm{~mm}-\mathrm{NADH}$. Active fractions were pooled and concentrated to $11 \mathrm{ml}$ by ultrafiltration.

The concentrate was applied to a Pharmacia Phenyl Superose HR $5 / 5$ column (FPLC) equilibrated with $25 \mathrm{~mm}-\mathrm{Tris} / \mathrm{HCl}$, pH 8.0. Proteins were eluted with a gradient from 1.7 to $0 \mathrm{M}\left(\mathrm{NH}_{4}\right)_{2} \mathrm{SO}_{4}$ in a volume of $40 \mathrm{ml}$, using a flow rate of $0.5 \mathrm{ml} \mathrm{min}^{-1}$. A sample of the eluate $(0.6 \mathrm{ml})$ containing reductase activity was dialysed against $25 \mathrm{mM}-\mathrm{Tris} / \mathrm{HCl}, \mathrm{pH} 8 \cdot 0$, and applied to a Pharmacia Mono Q HR 5/5 column equilibrated with $25 \mathrm{mM}-\mathrm{Tris} / \mathrm{HCl}, \mathrm{pH} 8 \cdot 0$. The elution was performed at a flow rate of $1 \mathrm{ml} \mathrm{min}{ }^{-1}$ with a gradient from 0 to $0.5 \mathrm{M}$ $\mathrm{NaCl}$ in a volume of $20 \mathrm{ml}$ followed by a gradient from 0.5 to $1 \mathrm{M}-\mathrm{NaCl}$ in a volume of $10 \mathrm{ml}$.

Determination of molecular mass. The molecular mass of quinone reductases purified by Phenyl Superose was estimated by gel filtration on a Pharmacia Superose 12 column (FPLC). A $200 \mu$ l sample of the protein solution was applied to the gel filtration column which was equilibrated with $30 \mathrm{~mm}-\mathrm{Tris} / \mathrm{HCl}, \mathrm{pH} 8.0$, containing $50 \mathrm{~mm}-\mathrm{NaCl}$ and $2 \%(\mathrm{v} / \mathrm{v})$ glycerol. The flow rate was $0.5 \mathrm{ml} \mathrm{min}^{-1}$. Protein standards from Pharmacia were used to calibrate the column.

In addition, SDS-PAGE was performed on a Phast System (Pharmacia) with $10-15 \%(\mathrm{w} / \mathrm{v})$ polyacrylamide gradient gels. The gels were silver stained according to the Phast System protocol. The standard protein mixture was from Pharmacia.

Isoelectric focusing. Agarose IEF gels, $\mathrm{pH} 4-8$, were prepared with $0.95 \mathrm{ml}$ Bio-Lyte $4-6$ and $0.95 \mathrm{ml} \mathrm{Bio-Lyte} \mathrm{6-8}$. Isoelectric points were determined with standard proteins from Serva. IEF pH 4-6.5 for twodimensional electrophoresis was performed on the Phast System according to the Phast System protocol.

Activity staining. In IEF gels the quinone reductases were activitystained. The staining solution contained $25 \mathrm{~mm}-\mathrm{Tris} / \mathrm{HCl}, \mathrm{pH} 8 \cdot 0$, $2 \mathrm{mM}-\mathrm{MTT}$ tetrazolium, $1 \mathrm{mM}-\mathrm{NADH}$ and $50 \mu \mathrm{M}-\mathrm{QI}$, II or IV. The enzymically produced hydroquinones reduced MTT tetrazolium to MTT formazan, a violet insoluble dye (Höjeberg et al., 1981).

Product analysis. The products of the enzymic reaction were analysed by HPLC (Merck-Hitachi System 655A-12). The reaction mixture contained $40 \mathrm{U}$ quinone reductase $\mathrm{ml}^{-1}, 0.25 \mathrm{~mm}$-quinone, $0.5 \mathrm{~mm}$ $\mathrm{NADH}$ and $10 \mathrm{~mm}-\mathrm{NH}_{4} \mathrm{HCO}_{3}, \mathrm{pH} 7.8$. Samples were taken at 


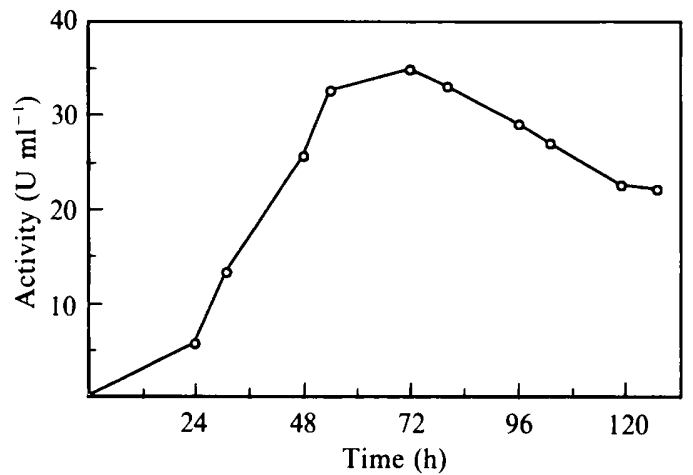

Fig. 2. Time course of quinone reductase activity in crude extracts of $\mathbf{N}$ limited cultures of $P$. chrysosporium, measured with QIV as the substrate. See Methods for details of the assay. The experiment was repeated three times; representative results are shown.

intervals of $15 \mathrm{~min}$, and $20 \mu \mathrm{l}$ of the sample was loaded on a Nucleosil RP 18 column (Bischoff-Analysentechnik). The eluent (flow rate $1 \mathrm{ml}$ $\min ^{-1}$ ) was a mixture of water and $20 \%(\mathrm{v} / \mathrm{v})$ methanol for QI, $30 \%$ methanol for QII and $40 \%$ methanol for QIV. The absorbance of the eluent was measured at $275 \mathrm{~nm}$.

\section{Results and Discussion}

\section{Production of quinone reductases}

A time course of reductase activity measured with QIV in N-limited cultures is shown in Fig. 2. The activity reached a maximum of $35 \mathrm{U} \mathrm{ml}^{-1}$ after $72 \mathrm{~h}$. At this point of cultivation the ligninolytic enzyme system of $P$. chrysosporium is activated by nitrogen starvation (Keyser et al., 1978; Ulmer et al., 1983).

Vanillic acid and veratryl alcohol were tested as inducers of quinone reductase activity since they have been shown to induce the ligninolytic system (Leisola $e t$ al., 1984). When $1.5 \mathrm{~mm}$-vanillic acid was added to $\mathrm{N}$ limited cultures after $3 \mathrm{~d}$, a $4 \cdot 1-$ to $4 \cdot 5$-fold increase in activity was observed after $5.5 \mathrm{~d}$ depending on the substrate used in the enzyme assay. These results are in accordance with those of Buswell et al. (1979). In Climited cultures a 26- to 42-fold increase in reductase activity was found after addition of vanillic acid. This is consistent with the suggestion of Ander et al. (1980) that quinone reductases are involved in the catabolism of vanillic acid. The greater increase of activity in cultures grown under $\mathrm{C}$-limited conditions may have resulted from their ability to use vanillic acid as a carbon source. Veratryl alcohol was only a weak inducer of reductase activity in N-limited cultures, and actually decreased the activity when added to $\mathrm{C}$-limited cultures at the beginning of cultivation (data not shown).

Several quinones have been identified as reaction
Table 1. Quinone reductase activity in crude extracts of $\mathrm{N}$ limited and C-limited cultures of $P$. chrysosporium with various inducers and substrates

Quinones QI, QII or QIV were used as inducers (1 mM) and as substrates in the enzyme assay $(250 \mu \mathrm{M})$. See Methods for details. Quinone reductase activity is expressed as $\mathrm{U} \mathrm{ml}^{-1}$ and represents the mean of two experiments.

\begin{tabular}{|c|c|c|c|c|c|c|}
\hline \multirow[b]{3}{*}{ Inducer } & \multicolumn{3}{|c|}{$\mathbf{N}$-limited culture } & \multicolumn{3}{|c|}{ C-limited culture } \\
\hline & \multicolumn{3}{|c|}{ Enzyme substrate: } & \multicolumn{3}{|c|}{ Enzyme substrate: } \\
\hline & QI & QII & QIV & QI & QII & QIV \\
\hline None & 19 & 28 & 28 & $3 \cdot 2$ & $7 \cdot 5$ & $6 \cdot 0$ \\
\hline QI & 14 & 19 & 22 & 13 & 20 & 19 \\
\hline QII & 105 & 167 & 176 & $7 \cdot 7$ & 11 & 11 \\
\hline QIV & 12 & 18 & 21 & 6.6 & 8.6 & $7 \cdot 1$ \\
\hline
\end{tabular}

products of the lignin model compound veratryl alcohol or its methyl ether when oxidized by lignin peroxidase (Schmidt et al., 1989). Three of these quinones were also tested as inducers of reductase activity at a concentration of $1 \mathrm{mM}$. Their addition to the cultures after $3 \mathrm{~d}$ did not affect the growth of the fungus. All these quinones were able to increase quinone reductase activity in either Climited or N-limited cultures or in both of them. The highest activities were obtained in $\mathrm{N}$-limited cultures containing QII (Table 1). In C-limited cultures, adding QI resulted in higher activities than adding QII. QI and QIV stimulated quinone reductase activity only in Climited cultures.

A concentrate of crude cell extract obtained from $\mathrm{N}$ limited cultures was subjected to IEF (pH 4-8) to obtain information about the number of quinone reductases produced by the fungus. Activity staining of this gel with QI, QII or QIV as substrates revealed at least 10 quinone reductases with isoelectric points from 4.4 to 6.6 (Fig. 3). This finding contradicts the results of Schoemaker $e t$ al. (1989), who suggested that different quinone reductases specifically reduce QI, QII or QIV.

\section{Purification}

An intracellular quinone reductase from $P$. chrysosporium mycelium grown in $\mathrm{N}$-limited conditions in the absence of an inducer was purified 163-fold. Its specific activity was $65880 \mathrm{U} \mathrm{mg}^{-1}$ and the recovery of activity was $0.8 \%$ (Table 2). During the purification, the quinone reductase activities were measured with QI, QII and QIV. However, data are shown only for QIV, since the purification did not result in a separation of reductases specific for QI or QII.

The first purification step was a precipitation with $10 \%$ PEG. The resulting pellet contained no quinone reductase activity and was discarded. Thirty-seven 
Table 2. Purification of quinone reductases from P. chrysosporium

The enzyme activities shown were determined with QIV as substrate. The purification procedure was performed three times with the exception of the anion-exchange chromatography, which was done only once. The values from one representative experiment are shown.

\begin{tabular}{lcccccc}
\hline \hline & $\begin{array}{c}\text { Volume } \\
(\mathrm{ml})\end{array}$ & $\begin{array}{c}\text { Activity } \\
\left(\mathrm{U} \mathrm{ml}^{-1}\right)\end{array}$ & $\begin{array}{c}\text { Protein concn } \\
\left(\mu \mathrm{g} \mathrm{ml}^{-1}\right)\end{array}$ & $\begin{array}{c}\text { Sp. act. } \\
\left(\mathrm{U} \mathrm{mg}^{-1}\right)\end{array}$ & $\begin{array}{c}\text { Yield } \\
(\%)\end{array}$ & $\begin{array}{c}\text { Purification } \\
\text { factor }\end{array}$ \\
\hline Crude extract & 720 & 224 & 557 & 403 & 100 & \\
PEG precipitation & 880 & 156 & 228 & 685 & 85 & $1 \cdot 7$ \\
Blue Sepharose & 280 & 88 & 32 & 2532 & 15 & $6 \cdot 3$ \\
Phenyl Superose & 3 & 2008 & 55 & 36670 & $3 \cdot 7$ & 89 \\
Mono Q & 1 & 1323 & 20 & 65880 & $0 \cdot 8$ & 163 \\
\hline \hline
\end{tabular}

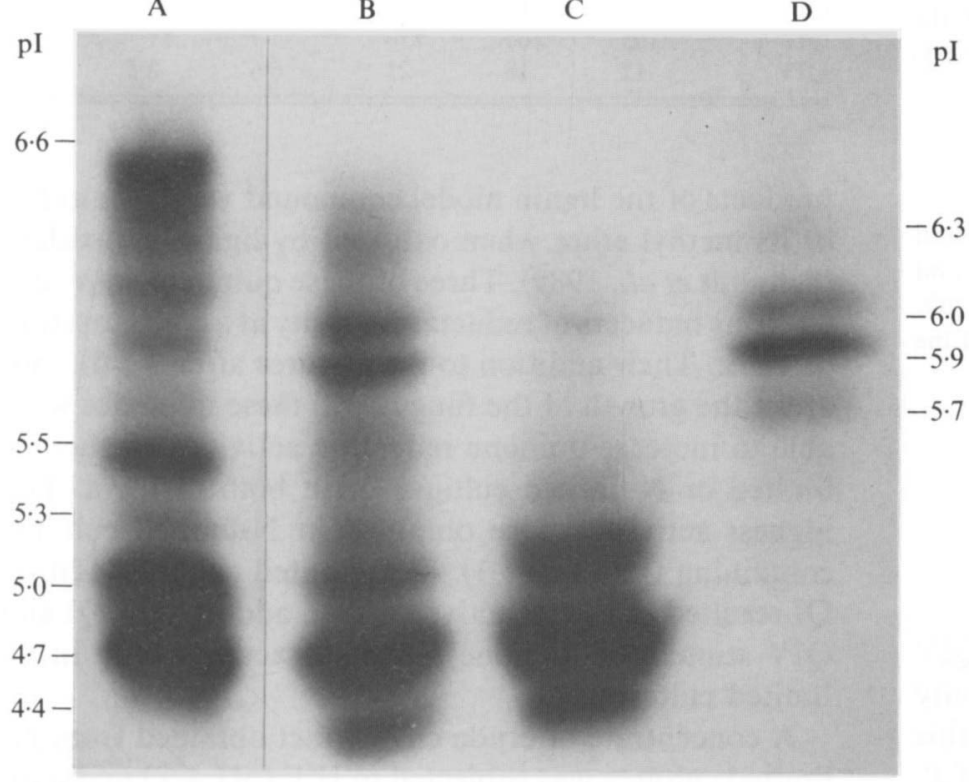

$\mathrm{pI}$

Fig. 3. IEF of the quinone reductases from $P$. chrysosporium. Active fractions were analysed on IEF gels $\mathrm{pH} \mathrm{4-8}$ and the reductases were detected by activity staining with quinone QIV. A, quinone reductases in the crude extract of $\mathrm{N}$-limited cultures; $\mathrm{B}$, quinone reductases purified by chromatography with Blue Sepharose; C, quinone reductases in the precipitate obtained by addition of $1.7 \mathrm{M}-\left(\mathrm{NH}_{4}\right)_{2} \mathrm{SO}_{4}$ to the fraction purified by Blue Sepharose; $\mathrm{D}$, quinone reductases purified by chromatography with Phenyl Superose. percent of the activity in the supernatant was adsorbed to Blue Sepharose in a batch process. Quinone reductase activity was eluted as one peak after packing the gel into a column. The addition of $1.7 \mathrm{M}-\left(\mathrm{NH}_{4}\right)_{2} \mathrm{SO}_{4}$ to the eluate precipitated $55 \%$ of the quinone reductase activity present. The reductases in this pellet were different from those in the supernatant, as shown by IEF (Fig. 3) and were not purified further. The supernatant was applied to a Phenyl Superose column for hydrophobic interaction chromatography. The quinone reductases eluted from this column as a single peak at a salt concentration of $0.97 \mathrm{M}$. Final purification was performed by an anionexchange chromatography. In this step, the quinone reductases eluted as a single peak at a salt concentration of $0 \cdot 14 \mathrm{M}$.

\section{Characterization}

Isoelectric focusing of the quinone reductases purified by Phenyl Superose chromatography revealed four bands with quinone reductase activity (Fig. 3, lane D). Their isoelectric points were $5 \cdot 7,5 \cdot 9,6 \cdot 0$ and $6 \cdot 3$.

SDS-PAGE and silver staining of quinone reductases further purified by anion-exchange chromatography revealed two bands, with molecular masses of $69 \mathrm{kDa}$ and $29 \mathrm{kDa}$. To identify the strong band at $69 \mathrm{kDa}$ as a quinone reductase, two-dimensional electrophoresis was performed. Reductases purified by Phenyl Superose chromatography were separated in the first dimension by IEF ( $\mathrm{pH}$ 4-6.5). Subsequent SDS-PAGE in the second dimension indicated that all four bands visualized by activity staining after IEF had the same molecular mass of $69 \mathrm{kDa}$. To determine their molecular mass by gel filtration, the quinone reductases purified by Phenyl Superose chromatography were applied to a Superose 12 column. They eluted from this column as a peak corresponding to $47 \mathrm{kDa}$.

The difference between the molecular masses obtained by gel filtration and SDS-PAGE may be explained by the fact that the molecular mass determined by gel filtration depends on the shape of the molecule, whereas in SDSPAGE the mobility of a protein depends on its charge. A 
Table 3. Substrate specificity relative to $Q I V$ of quinone reductases from $P$. chrysosporium purified by hydrophobic interaction chromatography

\begin{tabular}{lc}
\hline \hline \multicolumn{1}{c}{ Substrate } & $\begin{array}{c}\text { Relative rate of } \\
\text { reduction (\%) }\end{array}$ \\
\hline QIV & $100^{*}$ \\
QI & 49 \\
QII & 91 \\
QIII & 56 \\
Methylbenzoquinone & 34 \\
3,5-Di-t-butyl,1,2-benzoquinone & 92 \\
2,3-Dimethoxy-5-methyl-1,4-benzoquinone & 46 \\
Tetramethyl-1,4-benzoquinone & 0 \\
2,6-Dimethyl-1,4-benzoquinone & 7 \\
1,4-Benzoquinone & 80 \\
\hline \hline
\end{tabular}

* $100 \%$ corresponds to $17 \mathrm{U} \mathrm{ml}^{-1}$.

similar dual molecular mass effect has been reported in the case of a protopectinase (Sakai, 1988).

The quinone reductases were most active at $\mathrm{pH} 8.5$ with QI as substrate, at $\mathrm{pH} 7.3$ with QII and at $\mathrm{pH} 8.0$ with QIV. At $\mathrm{pH} 5 \cdot 0$, activity with all three substrates was reduced to $25 \%$ of the maxima observed at the higher $\mathrm{pH}$ values. When stored for $1 \mathrm{~d}$ at $4{ }^{\circ} \mathrm{C}$ or frozen overnight at $-20^{\circ} \mathrm{C}$, the crude cell extract lost $50 \%$ of its activity. Similar losses occurred when extract was stored in the presence of $20 \%$ glycerol. The half-life of the purified reductase was $120 \mathrm{~h}$ at $4{ }^{\circ} \mathrm{C}$ and a protein concentration of $40 \mu \mathrm{g} \mathrm{l}^{-1}$. The enzyme was stable for one week at $-20{ }^{\circ} \mathrm{C}$ in the presence of $0.5 \mathrm{~mm}$-NADH.

The substrate specificity was tested with various substituted benzoquinones (Table 3). The $K_{\mathrm{m}}$ for QIV, which was the best substrate, was $115 \mu \mathrm{M}$. The $K_{\mathrm{m}}$ for NADH was $5 \mu \mathrm{M}$. The $K_{\mathrm{m}}$ for QIV was also determined in the resuspended pellet containing the reductase fraction obtained by precipitation with $1.7 \mathrm{M}-\left(\mathrm{NH}_{4}\right)_{2} \mathrm{SO}_{4}$ (Fig. 3, lane C). These reductases showed a $K_{\mathrm{m}}$ of $11 \mu \mathrm{M}$ for QIV. In contrast to the purified enzyme, this reductase fraction used not only NADH but also NADPH as a cosubstrate.

None of several NADH-oxidoreductase inhibitors [1 mM-5,5-diphenylhydantoin, $1 \mathrm{~mm}$-diethylbarbituric acid, $\quad 0.05 \mathrm{~mm}$-5,5-dithiobis-(2-nitrobenzoic acid), $0.05 \mathrm{~mm}$ dicumarol, $0.05 \mathrm{~mm}$-quercetin] decreased the activity of the purified quinone reductases by more than $20 \%$. In contrast, complete inactivation was achieved by adding $1 \mathrm{~mm}$-DTT. In crude cell extracts, $1 \mathrm{~mm}$-DTT inhibited the reduction of QI, II and IV completely, whereas the reduction of QIII was inhibited by only $17 \%$. Partial inactivation $(42 \%)$ by DTT was also observed with the reductase fraction precipitated with $1.7 \mathrm{M}$ $\left(\mathrm{NH}_{4}\right)_{2} \mathrm{SO}_{4}$. $P$. chrysosporium therefore produces at least one reductase which is specific for QIII and which is not inhibited by DTT. Similar results were reported by Schoemaker et al. (1989), who postulated that $P$. chrysosporium produces different intracellular quinone reductases specific for each of the quinone substrates. However, in this study we discovered ten reductases with low substrate specificity.

\section{Product formation}

The production of hydroquinones from QI, II and IV by purified quinone reductases was monitored by HPLC analysis. The hydroquinones were identified by comparing their retention times to those of authentic reference compounds. Each of the hydroquinones formed was found to react non-enzymically to further products. It is not known whether these compounds are also formed under physiological conditions. Analysis of the metabolites of QI, II and IV in the culture supernatants of $P$. chrysosporium is in progress and the results will be reported elsewhere.

We thank U. Tuor from our institute and Dr H. W. H. Schmidt from Givaudan (Dübendorf, Switzerland) for the kind gift of QI, II and III. We also acknowledge the help of U.Tuor in preparing QIV and the hydroquinones.

\section{References}

Ander, P., Hatakka, A. \& Eriksson, K. E. (1980). Vanillic acid metabolism by the white-rot fungus Sporotrichum pulverulentum. Archives of Microbiology 125, 189-202.

Ander, P., Chittra, M., Farrell, R. L. \& Eriksson, K. E. (1990). Redox reactions in lignin degradation: interactions between laccase, different peroxidases and cellobiose :quinone oxidoreductase. Journal of Biotechnology 13, 189-198.

BRADFORD, M. M. (1976). A rapid and sensitive method for the quantitation of microgram quantities of protein utilizing the principle of protein-dye binding. Analytical Biochemistry 72, 248254.

Buswell, J. A. \& Eriksson, K. E. (1988). NAD(P)H dehydrogenase (quinone) from Sporotrichum pulverulentum. Methods in Enzymology 161, 271-781.

Buswell, J. A., Hamp, S. \& ERIKsson, K. E. (1979). Intracellular quinone reduction in Sporotrichum pulverulentum by a $\mathrm{NAD}(\mathrm{P}) \mathrm{H}$ : quinone oxidoreductase. FEBS Letters 108, 229-232.

FIESER, L. F. \& FIESER, M. (1967). Reagents for Organic Synthesis, vol. 1, p. 1081. New York: John Wiley.

Gold, M. H., Kuwahara, M., Chiu, A. A. \& Glenn, J. K. (1984). Purification and characterization of an extracellular $\mathrm{H}_{2} \mathrm{O}_{2}$-requiring diarylpropane oxygenase from the white-rot basidiomycete Phanerochaete chrysosporium. Archives of Biochemistry and Biophysics 234, 353-362.

Hämmerl, S. D., Leisola, M. S. A. \& Fiechter, A. (1986). Polymerization of lignins by ligninases from Phanerochaete chrysosporium. FEMS Microbiology Letters 35, 33-36.

HIGUCHI, T. (1985). Degradative pathways of lignin model compounds. In Biosynthesis and Biodegradation of Wood Components, pp. 558-561 . Edited by T. Higuchi. London: Academic Press.

Höjeberg, B. O., Blomberg, K., Stenberg, S. \& Lind, C. (1981). Biospecific adsorption of hepatic DT-diaphorase on immobilized dicoumarol. Archives of Biochemistry and Biophysics 207, 205-216. 
KeYSER, P. J., KIRK, T. K. \& ZeIKUS, J. G. (1978). Ligninolytic enzyme system of Phanerochaete chrysosporium: synthesized in absence of lignin in response to nitrogen starvation. Journal of Bacteriology 135, 790-797.

Leisola, M. S. A., Ulmer, D. C., Waldner, R. \& Fiechter, A. (1984). Role of veratryl alcohol in lignin degradation by Phanerochaete chrysosporium. Journal of Biotechnology 1, 331-339.

Lowe, C. R. \& Pearson, J. (1984). Affinity chromatography on immobilized dyes. Methods in Enzymology 104, 22-23, 97-113.

Muheim, A., Waldner, R., Leisola, M. S. A. \& FieChTER, A. (1990). An extracellular aryl alcohol oxidase from the white-rot fungus Bjerkandera adusta. Enzyme and Microbial Technology 12, 204-209.

SAKAI, T. (1988). Protopectinase from yeasts and a yeastlike fungus. Methods in Enzymology 161, 335-350.

Schmidt, H. W. H., Haemmerli, S. D., Schoemaker, H. E. \& Leisola, M. S. A. (1989). Oxidative degradation of 3,4-dimethoxybenzyl alcohol and its methyl ether by the lignin peroxidase of Phanerochaete chrysosporium. Biochemistry 28, 1776-1783.

SchoemaKer, H. E. \& Leisola, M. S. A. (1987). Enzymatic lignin degradation. New developments. Proceedings of the 31st IUPAC Congress of Pure and Applied Chemistry, section 4, 267-280.

Schoemaker, H. E., MeiJer, E. M., Leisola, M. S. A., Haemmerli, S. D., Waldner, R., SANGlard, D. \& Schmidt, H. W. H. (1989). Oxidation and reduction in lignin biodegradation. In Plant Cell Wall Polymers: Biogenesis and Biodegradation (ACS Symposium no. 399), pp. 454-471. Washington, DC: American Chemical Society.

TIEN, M. \& KIRK, T. (1983). Lignin-degrading enzyme from the hymenomycete Phanerochaete chrysosporium Burds. Science 221, 661-663.

Ulmer, D., Leisola, M. S. A., Puhakka, J. \& Fiechter, A. (1983). Growth pattern and lignin degradation. European Journal of Applied Microbiology and Biotechnology 18, 153-157.

Westermark, U. \& ERIKSSON, K. E. (1974a). Carbohydrate dependent enzymic quinone reduction during lignin degradation. Acta Chemica Scandinavica 28, 204-208.

Westermark, U. \& Eriksson, K. E. (1974b). Cellobiose:quinone oxidoreductase, a new wood-degrading enzyme from white-rot fungi. Acta Chemica Scandinavica 28, 209-214. 